Case Report

\title{
Increased Anti-mullerian Hormone (AMH) After Delivery: Case Report
}

\author{
Keiichi Kumasawa , Yuri Yasui, Hitomi Nakamura, Tadashi Kimura \\ Division of Obstetrics and Gynecology, Osaka University Graduate School of Medicine, Suita, Osaka, Japan
}

\section{Email addresses:}

kumasawa@gyne.med.osaka-u.ac.jp (K. Kumasawa),kokoko52@hotmail.com (K. Kumasawa),myuumyuu624@gmail.com (Y. Yasui), hitomi@gyne.med.osaka-u.ac.jp (H. Nakamura), tadashi@gyne.med.osaka-u.ac.jp (T. Kimura)

${ }^{*}$ Corresponding author

\section{To cite this article:}

Keiichi Kumasawa, Yuri Yasui, Hitomi Nakamura, Tadashi Kimura. Increased Anti-mullerian Hormone (AMH) After Delivery: Case Report. Journal of Gynecology and Obstetrics. Vol. 4, No. 3, 2016, pp. 17-18. doi: 10.11648/j.jgo.20160403.12

Received: June 15, 2016; Accepted: June 25, 2016; Published: July 15, 2016

\begin{abstract}
Anti-mullerian hormone (AMH) is mainly produced by antral follicles. AMH is widely used as a useful biomarker to reflect ovarian reserve and it was reported to reveal less changes during the course of pregnancy and early puerperium. A 29-year old woman visited our hospital for infertility treatment. Her serum level of AMH was $1.12 \mathrm{ng} / \mathrm{ml}$, which was lower for her age. She conceived by intra-uterine sperm insemination (IUI) treatment with clomiphen citrate. About 6 months after delivery, her serum level of AMH rose up to $3.34 \mathrm{ng} / \mathrm{ml}$, which was about the average level for her age. This result indicated that even if the serum AMH level is low initially, there is the possibility for higher levels of serum AMH at a later date.
\end{abstract}

Keywords: Anti-mullerian Hormone (AMH), Ovarian Reserve, Pregnancy, Delivery

\section{Introduction}

AMH is produced mainly by antral follicles. Recently $\mathrm{AMH}$ is widely used as a useful biomarker of ovarian reserve in the assisted reproductive technology. AMH is recognized to be superior to other markers such as basal FSH and inhibin B, etc [1-3].

The average serum AMH level in older women is lower than that of younger women of reproductive age [4]. Serum $\mathrm{AMH}$ level does not change during the menstrual cycle, various periods of pregnancy and early puerperium [5-8]. We report here that a patient who conceived after IUI and showed increasing serum AMH levels after her delivery.

\section{Case}

A 29-year-old nulliparaous woman with amenorrhea visited our hospital for infertility treatment. Routine examination for infertility treatment showed normal basal hormone levels and prolactin. However she refused a check of her serum AMH level. Using clomiphen citrate for ovulation induction, four cycles of timed intercourse and IUI were performed. After the $3^{\text {rd }}$ IUI treatment she agreed to have her serum level checked.

It was $1.13 \mathrm{ng} / \mathrm{ml}$, which was low for her age, compared to previous reported levels. While planning IVF treatment, she conceived after her $4^{\text {th }}$ IUI treatment.

During the course of pregnancy, fetal growth, and other screenings for pregnancy were within normal limits.

At $37+3$ weeks' gestational age, amniotic fluid index (AFI) was 4.7 , and the largest amniotic fluid pocket was $1.7 \mathrm{~cm}$. As she was diagnosised with hydramniosis, she was hospitalized to induce labor. On the day cervical canal dilation was performed because of immaturity of her cervix. Oxytosin was then administrated from the $37+4$ weeks' gestational age with epidural anesthesia. On the $37+5$ gestational week, she delivered a $2790 \mathrm{~g}(+0.12 \mathrm{SD})$ male baby with Apgar score 9/9. She was discharged from our hospital after recovering from dysuria as a side effect of prolonged labor. One month later after delivery, she visited our hospital to discuss the planning of her next pregnancy.

It is known that short interval pregnancy increases risk of preterm delivery, fetal growth restriction and intrauterine fetal death (IUFD), etc [9]. On the other hand, from the point of view of ovarian reserve and her low level of AMH, it seems 
better for her to become pregnant earlier. Therefore about six months after delivery we checked her serum AMH level again. It showed $3.34 \mathrm{ng} / \mathrm{ml}$, which was about three times higher than that before pregnancy (Table 1). Ultrasonographic examination showed that antral follicle count seemed to be increased and follicle growth became better compared to before. She devoted herself to care for her child, and was going to try for the next pregnancy one and a half years after her first delivery.

Table 1. Serum AMH level.

\begin{tabular}{ll}
\hline & AMH (ng/ml) \\
\hline before pregnancy (29 y. o.) & 1.12 \\
after delivery (31 y. o.) & 3.34 \\
\hline
\end{tabular}

\section{Discussion}

This is the first report of a woman who showed an approximately 3-fold increasing serum level of $\mathrm{AMH}$ increasing after 18 months which included delivery of her baby. During reproductive age, there is a tendency that as a woman ages, the serum AMH level becomes lower. However there is no significant correlation between serum AMH level and age, because of the large differences among individuals.

However, thus far, there is no previous report following up individual serum AMH levels over a long period. The serum $\mathrm{AMH}$ level has been reported to decrease significantly after laparoscopic bilateral ovarian cystectomy [10]. Individually serum AMH level does not significantly change throughout the menstrual cycle. Moreover serum AMH level does not change between various periods of pregnancy and early puerperium.

Therefore, taking these observations into consideration, AMH level seems to decrease gradually. The initial serum AMH level was $1.12 \mathrm{ng} / \mathrm{ml}$, and after nearly one and a half years later, it had risen up to $3.34 \mathrm{ng} / \mathrm{ml}$. If the serum AMH level post-delivery had been lower compared to the previous value, we would have intended to retrieve and preserve eggs for embryo transfer (ET) after one year, which corresponded to the time period one and a half years after delivery. There was no drastic event except pregnancy and delivery between the two points of testing of serum AMH. Thus far, it is difficult to determine what affected serum AMH level. The initial low level of AMH may have been transiently low or the recovery of serum AMH level may have been transiently high. She did not attend our hospital and therefore we could not follow her serum AMH level over time. This result indicated that even if the serum AMH level is low, there is the possibility of a higher level of serum AMH at a future time. Thus far, which of the different serum AMH levels reflect her ovarian reserve more appropriately was not to be seen. For further understanding of AMH and ovarian reserve, accumulation of data should be needed.

\section{Conclusion}

The importance of this case report is the fact serum AMH level can be elevated after delivery. Therefore, once serum AMH level is found to be low, examination for the second time may be meaningful and encouraging. Further research with a lot of patients will be needed.

\section{References}

[1] B. F. van Rooij IA, Scheffer GJ, Looman CW, Habbema JD, de Jong FH, Fauser BJ, Themmen AP, te Velde ER "Serum antimullerian hormone levels best reflect the reproductive decline with age in normal women with proven fertility: a longitudinal study" Fertil Steril, Vol 83, pp 979-987, Apr 2005.

[2] K. S. Al-Azemi M 1, Duffy S, Pye C, Refaat B, Hill N, Ledger W "Multi-marker assessment of ovarian reserve predicts oocyte yield after ovulation induction." Hum Reprod Vol 26, pp 414-422, Feb 2011.

[3] H. G. Hansen KR 1, Knowlton N, Craig LB "Correlation of ovarian reserve tests with histologically determined primordial follicle number." Fertil Steril, Vol 95, pp 170-175 Jan 2011.

[4] V. J. Lie Fong S, Welt CK, de Rijke YB, Eijkemans MJ, Broekmans FJ, Rose EM, Peters WH, Hokken-Koelega AC, Fauser BC, Themmen AP, de Jong FH, Schipper I, Laven JS "Serum anti-müllerian hormone levels in healthy females: a nomogram ranging from Infancy to adulthood" J Clin Endocrinol Metab Vo. 97, pp 4650-4655, Dec 2012.

[5] G. S. La Marca A, Orvieto R, De Leo V, Volpe A "Anti-Müllerian hormone concentrations in maternal serum during pregnancy" Hum Reprod, Vol 20, pp 1569-1572, Jan 2005 .

[6] K. A. Köninger A 1, Schmidt B, Schmidt M, Yerlikaya, G, Kasimir-Bauer S, Kimmig R, Birdir C "Anti-Mullerian-hormone levels during pregnancy and postpartum", Reprod Biol Endocrinol, Jul 2013.

[7] F. P. Massé V 1, Boucoiran I, Delotte J, Isnard V, Bongain A "Normal serum concentrations of anti-Mullerian hormone in a population of fertile women in their first trimester of pregnancy" Hum Reprod, Vol 26, pp 3431-3436, Dec 2011.

[8] d. M. J. Streuli I 1, Paccolat C 3, Chapron C 4, Petignat P 3, Irion OP 3, de Ziegler D 2 " AMH concentration is not related to effective time to pregnancy in women who conceive naturally" Reprod Biomed Online, Feb 2014.

[9] E. S. DeFranco EA, Muglia LJ "Influence of interpregnancy interval on birth timing" BJOG Vol 121, pp 1633-1640, Dec 2014.

[10] H. W. Iwase A, Goto M, Takikawa S, Nagatomo Y, Nakahara T, Manabe S, Kikkawa F., "Serum anti-Müllerian hormone level is a useful marker for evaluating the impact of laparoscopic cystectomy on ovarian reserve" Fertil Steril, Vol 94, pp 2846-2849 Dec 2010. 